\title{
Pengaruh Medication Therapy Management (MTM) Terhadap Pengetahuan dan Kepatuhan Pasien Hipertensi di Puskesmas Kota Yogyakarta
}

Esti Asadina ${ }^{1}$, Nanang Munif Yasin $^{2 *}$, Susi Ari Kristina

${ }^{1}$ Program Studi Magister Farmasi Klinik, Fakultas Farmasi, Universitas Gadjah Mada, Yogyakarta, Indonesia

${ }^{2}$ Departemen Farmakologi dan Farmasi Klinik, Fakultas Farmasi, Universitas Gadjah Mada, Yogyakarta, Indonesia

${ }^{3}$ Departemen Farmasetika, Fakultas Farmasi, Universitas Gadjah Mada, Yogyakarta, Indonesia

*Corresponding author: nanangy@yahoo.com

Submitted: 23 Maret 2020

Accepted: 22 Juli 2020

Published: 27 April 2021

\begin{abstract}
Background: Hypertension is a chronic disease that causes death in cardiovascular cases both globally and in Indonesia. Treatment of hypertension is long-term commitment. Therefore, good knowledge and adherence are needed. Improving the patient's knowledge will lead to better health behaviors that affect adherence in treatment and control of blood pressure. Medication Therapy Management (MTM) is one method that can be used to improve the knowledge and adherence of hypertensive patients. Objective: This study aims to determine the effectiveness of Medication Therapy Management (MTM) on the knowledge and adherence of patients with hypertension in Yogyakarta City Health Center. Method: The study used quasi-experimental one group design with pre-testposttest design. Data were analyzed statistically using Wilcoxon test to compare knowledge and adherence of the patients. Result: Forty-four people participated in this study, 63.6\% of the respondents are women, the most age is 55 - 64 years (40.9\%), the average education level is senior high school (59.1\%), patients suffer from hypertension for an average of $1-10$ years and $15.9 \%$ with complications of DM, 6.8\% with hyperlipidemia and $9.1 \%$ with DM + hyperlipidemia. The results of the study obtained an average increase in knowledge scores after MTM from $14.3 \pm 3.766$ to 20, $32 \pm 2,399(p=0,000)$ and a decrease in the average adherence score of $1.64 \pm$ 1.464 to $0.39 \pm 0.920(p=0,000)$. Conclusion: This study concluded that Medication Therapy Management (MTM) by a pharmacist significantly increased patient knowledge and improved patient adherence.
\end{abstract}

Keywords: medication therapy management, MTM, hypertension, adherence, knowledge

\begin{abstract}
Abstrak
Pendahuluan: Hipertensi adalah salah satu penyakit kronis penyebab kematian pada kasus kardiovaskular di dunia maupun di Indonesia. Pengobatan hipertensi dilakukan dalam jangka waktu panjang, sehingga diperlukan pengetahuan dan kepatuhan yang baik terkait hipertensi. Peningkatan pengetahuan akan mengarah pada kemajuan berpikir tentang perilaku kesehatan yang lebih baik sehingga berpengaruh terhadap kepatuhan dalam pengobatan dan terkontrolnya tekanan darah. Medication Therapy Management (MTM) adalah salah satu metode yang digunakan untuk meningkatkan pengetahuan dan kepatuhan pasien hipertensi secara individual. Tujuan: Penelitian ini bertujuan untuk mengetahui pengaruh pelayanan berbasis Medication Therapy Management (MTM) terhadap pengetahuan dan kepatuhan pasien hipertensi di Puskesmas Kota Yogyakarta. Metode: Metode yang digunakan adalah quasi-experimental one group with pretest-posttest design. Data dianalisis secara statistik menggunakan Wilcoxon test untuk mengetahui perbedaan hasil sebelum dan sesudah pemberian intervensi. Hasil: Penelitian ini diikuti oleh 44 orang, 63,6\% jumlah responden yaitu perumpuan, usia paling banyak 55 - 64 tahun 40,9\%, rata-rata pendidikan terakhir adalah SMA 59,1\%, lama pasien menderita hipertensi rata-rata 1 - 10 tahun serta 15,9\% dengan komplikasi DM, 6,8 \% dengan hiperlipidemia dan 9,1\% dengan DM + Hiperlipidemia. Hasil penelitian diperoleh peningkatan rata-rata skor pengetahuan setelah mendapatkan pelayanan berbasis MTM yaitu dari 14,3 $\pm 3,766$ menjadi 20,32 $\pm 2,399$ dengan $p=0,000$ dan penurunan rata-rata skor kepatuhan yaitu 1,64 \pm 1,464 menjadi 0,39 $\pm 0,920$. Kesimpulan: Dapat disimpulkan bahwa intervensi dengan metode pelayanan berbasis
\end{abstract}


Medication Therapy Management (MTM) oleh apoteker terbukti meningkatkan pengetahuan pasien mengenai penyakit hipertensi dan pengobatannya secara bermakna dan berperan signifikan dalam meningkatkan kepatuhan pasien hipertensi.

Kata kunci: medication therapy management, MTM, hipertensi, kepatuhan, pengetahuan

\section{PENDAHULUAN}

Hipertensi adalah salah satu penyakit kronis yang paling banyak terjadi dan merupakan faktor risiko utama penyebab kematian pada kasus kardiovaskular (Ribeiro dkk., 2015). Di Indonesia, kasus hipertensi yang tidak terkontrol semakin meningkat seiring dengan pertumbuhan populasi dan penuaan. Hasil riset kesehatan dasar tahun 2013 menempatkan D.I Yogyakarta pada urutan ketiga jumlah kasus hipertensi di Indonesia berdasarkan diagnosis dan atau riwayat minum obat (Kemenkes RI, 2013). Hambatan dalam pengobatan hipertensi salah satu diantaranya disebabkan kurangnya pengetahuan terkait hipertensi (Lee dkk., 2013). Pasien yang memiliki pengetahuan baik akan berdampak pada terkontrolnya tekanan darah (Akoko dkk., 2017). Pengetahuan pasien tentang hipertensi dibutuhkan untuk meningkatkan kepatuhan pengobatan (Jankowska-Polańska dkk., 2016). World Health Organization (WHO) menegaskan bahwa rendahnya kepatuhan merupakan penyebab paling penting dari tekanan darah yang tidak terkontrol (WHO, 2003).

Medication Therapy Management (MTM) adalah salah satu metode terbaru yang dapat digunakan untuk meningkatkan pengetahuan dan kepatuhan pasien hipertensi. Tujuan penerapan Medication Therapy Management (MTM) adalah untuk penggunaan obat yang aman dan efektif, meningkatkan kualitas pengobatan, mengoptimalkan hasil pengobatan pasien, dan mengurangi biaya pengobatan (Wittayanukorn dkk., 2013). Medication Therapy Management (MTM) terdiri dari 5 elemen inti diantaranya adalah Medication Therapy Review (MTR) yang berisi penggalian informasi pada pasien oleh apoteker, Personal Medication Record (PMR) yang diaplikasikan dengan adanya catatan kartu pengobatan pasien yang disimpan oleh tenaga kesehatan dan pasien, Medication Related Action Plan yaitu tindakan yang akan dilakukan untuk mengatasi permasalahan terkait terapi pasien, intervensi terkait solusi dan tindakan yang akan dilakukan terhadap permasalahan terapi pasien, serta dokumentasi dan follow up yang mencakup pencatatan terhadap semua kegiatan yang dilakukan dan didokumentasikan dalam catatan pengobatan pasien. Dengan adanya 5 elemen inti ini diharapkan dapat terjadinya kolaborasi yang baik antar tenaga kesehatan dan pasien. Kelebihan pelayanan berbasis MTM adalah pada pelayanan berbasis MTM mengedepankan kolaborasi antara apoteker dengan dokter dan tenaga profesional kesehatan lainnya untuk mengoptimalisasikan penggunaan obat sesuai EBM (Evidence Based Medicine) dengan melibatkan peran aktif pasien dalam mengelola kesehatannya sendiri. Seluruh kegiatan yang dilakukan oleh semua tenaga kesehatan akan didokumentasikan pada kartu catatan pengobatan pasien yang disimpan oleh apoteker dan pasien. Pada penelitian ini intervensi pelayanan berbasis MTM yang dilakukan mengacu pada pelayanan berbasis MTM yang dibuat oleh BPJS kemudian dilakukan dimodifikasi dan disesuaikan dengan keadaan yang ada di puskesmas tempat penelitian.

Penelitian yang dilakukan oleh Sam dkk. (2017) diperoleh hasil yaitu terdapat peningkatan pengetahuan dan kepatuhan pada pasien dengan penyakit kronis salah satunya hipertensi dengan menggunakan metode Medication Therapy Management (MTM) (Sam dkk., 2017). Penelitian terkait pelayanan MTM di Indonesia belum dilakukan, tetapi penelitian serupa sebelumnya telah banyak dilakukan yaitu tentang pengaruh intervensi apoteker terhadap tingkat pengetahuan, tingkat kepatuhan, outcome klinik dan kualitas hidup pasien hipertensi. Studi-studi ini mengatakan terdapat hubungan yang signifikan antara intervensi apoteker dengan tingkat pengetahuan dan tingkat kepatuhan. Penelitian yang dilakukan oleh Widyastuti dkk. (2019) di menunjukan hasil adanya peningkatan pengetahuan $(\mathrm{p}=0,000)$ sehingga terjadi peningkatan kepatuhan $(\mathrm{p}=$ 0,000 ), terjadi penurunan tekanan darah sistolik dengan $(\mathrm{p}=0,000)$ dan diastolik $(\mathrm{p}=0,000)$ dan kualitas hidup pasien meningkat dengan nilai $(\mathrm{p}=0,001)$ (Widyastuti dkk., 2019). Penelitian lainnya menggunakan metode konseling oleh apoteker yang dilakukan oleh Kristina dkk. (2019) tentang evaluasi efektivitas metode konseling oleh apoteker terhadap kepatuhan pasien terhadap obat antihipertensi dan kontrol tekanan darah di Puskesmas Kota Yogyakarta, pengukuran kepatuhan pengobatan antihipertensi diukur dengan Morisky Green Levine Scale (MGLS) diperoleh hasil bahwa metode 
tersebut efektif untuk meningkatkan kepatuhan pengobatan dan hasil tekanan darah di antara pasien hipertensi. Efektivitas metode konseling oleh apoteker dalam meningkatkan kepatuhan pengobatan ditunjukkan oleh skor perubahan skor MGLS selama 4 minggu masa studi (Kristina dkk., 2019). Di Indonesia, pemerintah bersama dengan BPJS (Badan Penyelenggara Jaminan Sosial) kesehatan saat ini mencanangkan pelayanan berbasis MTM (Medication Therapy Management). Penelitian ini diharapkan dapat meningkatkan pengetahuan dan kepatuhan pasien hipertensi di Puskesmas Kota Yogyakarta dengan menggunakan metode pelayanan berbasis Medication Therapy Management (MTM).

\section{METODE}

\section{Rancangan penelitian}

Penelitian ini menggunakan rancangan penelitian quasi eksperimental one group with pretest-posttest design dan pengukuran variabel setelah 30 hari yang bertujuan untuk mengetahui pengaruh dari pemberian intervensi tertentu yang pada selang waktu tertentu kepada kelompok objek yang diteliti, dengan membandingkan hasil post-test dan pre-test berdasarkan skor kuesioner pengetahuan Hypertension Knowledge Level Scale (HK-LS) serta kuesioner kepatuhan Morisky Green Level Scale (MGLS). Penelitian ini dilakukan pada bulan Maret - April 2020 di Puskesmas Umbulharjo II dan Mergangsan Kota Yogyakarta. Pemilihan puskesmas pada penelitian ini ditetapkan setelah dilakukan survey terhadap apoteker oleh peneliti dengan mengisi informed consent yang berisi bahwa apoteker bersedia/siap melaksanakan pelayanan berbasis MTM Penelitian ini telah memperoleh izin Komisi Etik Penelitian Kesehatan Fakultas Kedokteran Universitas Gadjah Mada dengan No: KE/FK/0710/EC496/EC/2019.

\section{Pengumpulan data}

Teknik pengambilan sampel penelitian menggunakan teknik non-random dengan cara purposive sampling sesuai dengan kriteria inklusi dan eksklusi yang telah ditentukan. Jumlah populasi yaitu 300 pasien hipertensi dengan masing-masing puskesmas sebanyak 150 pasien dan untuk jumlah populasi puskesmas yaitu 18 puskesmas. Kriteria inklusi penelitian adalah pasien dengan hipertensi rawat jalan dengan atau tanpa penyakit penyerta yang menjalani kontrol rutin minimal 1 bulan sebelum penelitian, menyetujui informed consent dan bersedia mengisi kuesioner serta apoteker yang bersedia menjalankan pelayanan berbasis Medication Therapy Management (MTM) di puskesmas. Pasien yang tidak dapat berkomunikasi dengan baik, tidak menyelesaikan kuesioner yang diberikan, dan tidak kontrol rutin selama penelitian dieksklusi dari penelitian ini. Pengambilan data pengetahuan dan kepatuhan dilakukan dengan menggunakan kuesioner Hypertension Knowledge Level Scale (HK-LS) untuk mengukur pengetahuan dan Morisky Green Level Scale (MGLS) untuk mengukur kepatuhan.

\section{Alat ukur}

Kuesioner yang digunakan untuk mengukur pengetahuan adalah Hypertension Knowledge Level Scale (HK-LS). Hypertension Knowledge Level Scale (HK-LS) terdiri dari 22 item pertanyaan dimana data yang diperoleh berupa data interval yaitu "benar" atau "salah". Pada penelitian yang dilakukan Baliz dkk. (2012) kuesioner ini memiliki nilai alpha cronbach 0,82. Hypertension Knowledge Level Scale (HK-LS) dikategorikan menjadi 3 kategori skor pengetahuan yaitu tinggi $(16$ - 22) sedang (8 - 15) rendah $(0-7)$. Morisky Green Level Scale (MGLS) adalah kuesioner yang digunakan untuk menilai kepatuhan terkait minum obat. Jumlah seluruh pertanyaan berjumlah 4 dan data yang diperoleh berupa data interval yaitu "Ya" atau "Tidak" (Beyhaghi dkk., 2016). Kuesioner ini telah digunakan secara luas dan memiliki nilai alpha cronbach 0,7 - 0,9 (Beyhaghi dkk., 2016). MG-LS dikategorikan menjadi 3 kategori skor kepatuhan yaitu tinggi (0) sedang (1 - 2) rendah (3 - 4). Kuesioner yang digunakan dalam penelitian ini telah diterjemahkan kedalam bahasa Indonesia di lembaga pendidikan bahasa Inggris Universitas Gadjah Mada yang disesuaikan dengan bentuk aslinya yaitu bahasa Inggris dan dilakukan facevalidity kepada 30 pasien hipertensi ditempat penelitian dengan cara memberikan 8 item pertanyaan yang berisi pertanyaan tentang gaya bahasa dan ejaan, urutan dan kejelasan pertanyaan, pemahaman responden serta waktu wawancara yang digunakan setelah responden membaca 2 kuisioner. Hasil facevalidity memiliki rata-rata $90 \%$ yang artinya responden memahami isi pertanyaan dari kuisioner. Instrumen lain yang digunakan dalam penelitian ini diantaranya adalah leaflet yang berisi informasiinformasi tentang hipertensi serta buku dokumentasi pelaksanaan pelayanan berbasis Medication Therapy Management (MTM) yang disebut sebagai "buku pintar" yang dibuat oleh tim peneliti. Buku dokumentasi dapat dilihat pada Gambar 1. 
Gambar 1. Buku dokumentasi pelayanan berbasis MTM
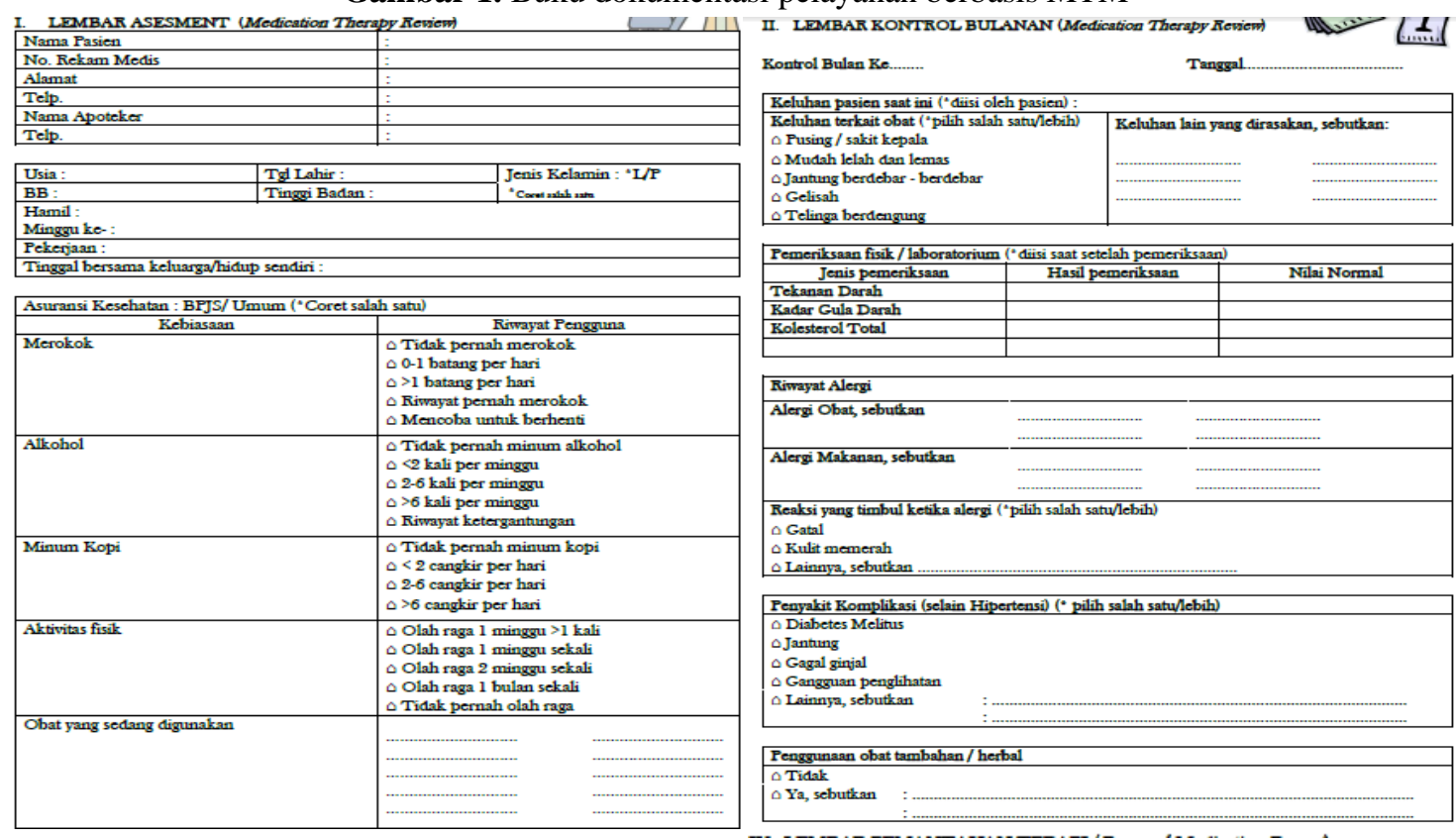

IV. LZMBAR PEMANTAUAN TERAPI (Personal Medication Record

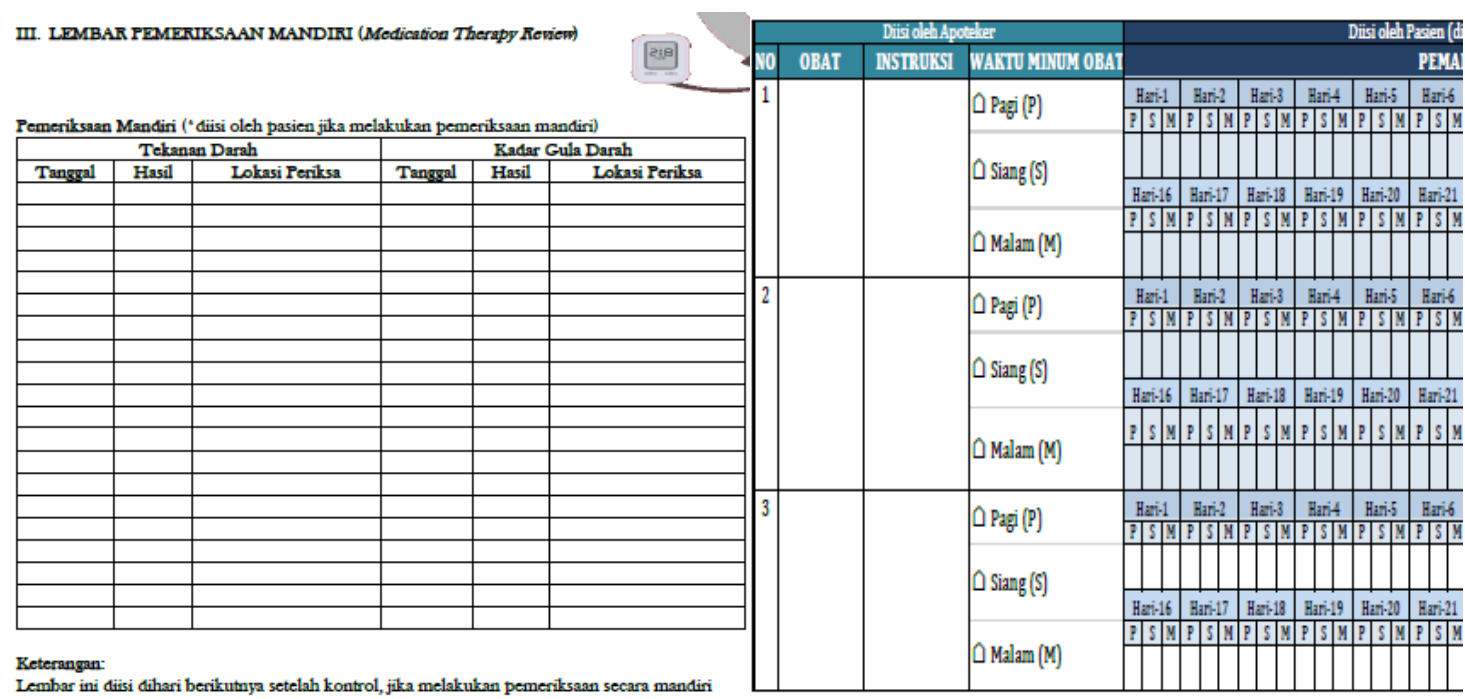

\section{Jalannya penelitian}

Medication Therapy Management (MTM) yang dilakukan pada penelitian ini menggunakan model pelayanan berbasis MTM dan bukan MTM murni seperti teori yang ada dan dimodifikasi sesuai keadaan di puskesmas tempat penelitian. Apoteker yang bersedia melaksanakan penerapan pelayanan berbasis MTM diberikan pelatihan dalam bentuk Focus Group Discussion (FGD). Dalam FGD apoteker diberikan pelatihan pelaksanaan pelayanan berbasis MTM dan Standar Prosedur Operasional serta diberikan buku dokumentasi pasien dan buku dokumentasi untuk disimpan oleh apoteker. Bentuk pelayanan yang dilakukan adalah asesmen, konseling, edukasi dari apoteker kepada pasien. Asesmen adalah pengumpulan informasi terkait masalah pengobatan pasien (Elemen
Medication Therapy Review) dan pemberian buku dokumentasi pasien (Elemen Personal Medication Record). Pada tahap asesmen, dilakukan pengumpulan informasi terkait identitas diri, riwayat kebiasaan, obat dan kondisi pasien saat ini kemudian dituliskan pada buku dokumentasi pasien. Konseling dan edukasi dilakukan oleh apoteker saat penyerahan obat sebagai bentuk pelayanan konsultatif untuk mengatasi masalah terkait obat (Elemen intervention), dan layanan kunjungan tindak lanjut yang diberikan oleh apoteker sesuai dengan kebutuhan pasien (Elemen follow-up), konseling yang dilakukan terkait solusi untuk keluhan pasien saat ini, obat yang diterima pasien serta cara penggunaan yang benar serta edukasi dalam bentuk leaflet (Elemen Medication Related Action Plan) yang berisi definisi hipertensi, terapi obat dan non obat, hal- 
hal yang boleh dan tidak dikonsumsi pasien, cara mengontrol tekanan darah, dan manfaat minum obat secara teratur dan menganjurkan pasien untuk membacanya. Apoteker menjelaskan lembar self monitoring pada buku dokumentasi dan menganjurkan agar pasien menuliskan tekanan darah jika melakukan pengecakan secara mandiri. Buku dokumentasi yang diterima pasien diberitahukan untuk dibawa saat kontrol. Apoteker juga menuliskan obat yang diterima pasien dan permasalahan serta solusi yang dilakukan jika ada permasalahan terkait obat dibuku dokumentasi yang disimpan oleh apoteker. Pada penelitian ini, pengambilan data dilakukan sebanyak 2 kali, yaitu pretest sebelum dilakukan MTM dan post-test setelah 1 bulan saat pasien kontrol. Pengamatan dilakukan dalam waktu singkat dikarenakan keterbatasan waktu penelitian dan masa studi tetapi implementasi pelayanan berbasis MTM dan intervensi oleh apoteker dapat diterapkan setelah penelitian selesai. Sebelum dilakukan MTM oleh apoteker, pasien terlebih dahulu mengisi informed consent dan data demografi serta mengisi kuesioner pengetahuan (HK-LS) dan kepatuhan (MGLS) sebagai data pretest.

\section{Analisis hasil penelitian}

Analisis dilakukan untuk mengetahui pengaruh MTM (variabel bebas) terhadap tingkat pengetahuan dan kepatuhan (variabel tergantung sebelum dan sesudah intervensi). Untuk melihat perbedaan hasil sebelum dan sesudah pemberian intervensi menggunakan analisis bivariat yaitu Paired sample $t$ test atau Wilcoxon test (berdasarkan hasil normalitas data). Pada penelitian ini menggunakan Wilcoxon test dikarenakan data tidak terdistribusi normal. Tingkat signifikansi yang digunakan dalam penelitian ini adalah $\mathrm{P}<0,05$.

\section{HASIL DAN PEMBAHASAN Karakteristik responden}

Penelitian ini dilakukan pada bulan Maret hingga April 2020 di Puskesmas Umbulharjo II dan Mergangsan Kota Yogyakarta. Jumlah pasien hipertensi yang dijadikan sampel sebanyak 44 sampel yang diberikan perlakuan berupa pelayanan berbasis Medication Therapy Mangement (MTM). Seluruh subjek dapat mengikuti penelitian hingga akhir pengambilan data, yaitu 30 hari. Distribusi frekuensi berdasar pada karakteristik responden dapat dilihat pada Tabel 1. Pada penelitian ini jumlah responden laki-laki lebih sedikit dari pada perempuan. Jumlah responden perempuan sebanyak 28 orang $(63,6 \%)$. Secara teori, umumnya laki-laki lebih banyak menderita hipertensi daripada perumpuan. Laki-laki sering mengalami tandatanda hipertensi pada usia akhir 30-an. Akan tetapi setelah perempuan memasuki masa menopause, prevalensi hipertensi akan meningkat dan resiko untuk menderita hipertensi lebih tinggi. Hal ini disebabkan karena produksi hormon estrogen menurun saat menopause, sehingga tekanan darah dapat meningkat. Prevalensi responden mempunyai usia < 45 tahun sebanyak 4 orang $(9,1 \%), 45$ - 54 tahun sebanyak 10 orang $(22,7 \%), 55$ - 64 tahun sebanyak 18 orang (40,9\%), 65 - 74 tahun 9 orang $(20,4 \%)$ dan usia $>75$ tahun 3 orang $(6,8 \%)$. Pada umumnya, hipertensi ditemui pada pasien berusia lanjut. Semakin bertambahnya usia seseorang, maka resiko terjadinya hipertensi akan semakin meningkat (Dipiro dkk., 2017). Pendidikan terakhir terbanyak adalah SMA yaitu 26 orang $(59,1 \%)$. Pekerjaan pasien terbanyak yaitu wiraswasta 13 orang $(29,5 \%)$. Jenis pekerjaan berkaitan dengan aktivitas fisik dari seseorang. Individu yang tidak aktif dalam melakukan suatu kegiatan akan cenderung memiliki frekuensi denyut jantung yang lebih tinggi sehingga otot jantung harus bekerja lebih keras yang menyebabkan tekanan yang dibebankan pada arteri semakin besar sehingga menyebabkan kenaikan tekanan darah (Sam dkk., 2017). Lama pasien menderita hipertensi memiliki frekuensi terbanyak yaitu 1 10 tahun sebanyak 26 pasien $(59,1 \%)$. Penyakit penyerta responden yaitu Diabetes melitus sebanyak 7 orang $(15,9 \%)$, hiperlipidemia yaitu 8 orang $(18,2 \%)$ dan $\mathrm{DM}+$ Hiperlipidemia sebanyak 4 orang $(9,1 \%)$. Responden rata rata dalam status menikah sebanyak 43 orang $(97,7 \%)$. Mayoritas responden menggunakan 1 jenis obat antihipertensi. Obat antihipertensi yang diterima responden terbanyak adalah amlodipin yaitu 41 pasien $(93,2 \%)$ dan sisanya menggunakan captopril 3 pasien $(6,8 \%)$. 
Tabel 1. Distribusi karakteristik responden

\begin{tabular}{cccc}
\hline & Karakteristik & Frekuensi & Persentase (\%) \\
\hline Jenis Kelamin & Laki-laki & 16 & 36,4 \\
& Perumpuan & 28 & 63,6 \\
Usia & $\leq 45$ tahun & 4 & 9,1 \\
& $45-54$ tahun & 10 & 22,7 \\
& $55-64$ tahun & 18 & 40,9 \\
Pendidikan terakhir & $65-74$ tahun & 9 & 20,4 \\
& $\geq 75$ & 3 & 6,8 \\
& SD & 4 & 9,1 \\
Pekerjaan & SMP & 2 & 4,5 \\
& SMA & 26 & 59,1 \\
& Universitas & 12 & 27,3 \\
& PNS & 5 & 11,3 \\
& Pegawai Swasta & 12 & 27,3 \\
& Wiraswasta & 13 & 29,5 \\
& Ibu Rumah Tangga & 10 & 22,7 \\
& Buruh & 1 & 2,4 \\
Lama Menderita & Tidak Bekerja & 3 & 6,8 \\
& $<1$ tahun & 11 & 25 \\
& 1 - 10 tahun & 26 & 59,1 \\
& 11 - 19 tahun & 6 & 13,6 \\
& 20 tahun & 1 & 2,3 \\
& Diabetes melitus & 7 & 15,9 \\
& Hiperlipidemia & 8 & 18,2 \\
& DM + Hiperlipidemia & 4 & 9,1 \\
\hline & & &
\end{tabular}

\section{Pengaruh MTM terhadap pengetahuan pasien hipertensi dan implikasinya terhadap praktek apoteker}

Penelitian ini untuk mengetahui pengaruh pelayanan berbasis Medication Therapy Management (MTM) terhadap tingkat pengetahuan dan kepatuhan pasien hipertensi. Metode ini diharapkan agar Apoteker mampu meningkatkan tingkat pengetahuan pasien tersebut sehingga muncul kesadaran untuk menjadi patuh dalam pengobatan. Hasil pengukuran dengan kuesioner pengetahuan dapat diketahui gambaran tingkat pengetahuan responden dan peningkatan pengaruh dari pemberian metode Medication Therapy Management (MTM) yang ditunjukkan dalam tabel 2. Berdasarkan Tabel 2, dapat dilihat peningkatan jumlah pasien yang masuk kategori pengetahuan tinggi berdasarkan skor Hypertension Knowledge Level Scale (HK-LS) setelah mendapatkan pelayanan berbasis MTM yaitu dari 36,4\% menjadi 95,4\%. Jumlah pasien yang berada pada kategori pengetahuan sedang turun dari $56,8 \%$ menjadi $4,5 \%$. Jumlah pasien yang berada pada kategori pengetahuan rendah turun dari 6,8\% menjadi 7,9\%. Berdasarkan tabel 2 dapat dilihat bahwa terjadi peningkatan skor dari hasil pre-test terhadap masing-masing pertanyaan, yang berarti terjadi peningkatan pengetahuan pasien terhadap penyakit hipertensi. Hasil uji tingkat pengetahuan menggunakan skor Hypertension Knowledge Level Scale (HKLS) pasien hipertensi rata-rata memiliki pengetahuan sedang $(14,3 \pm 3,766)$ dan setelah dilakukan MTM kategori pengetahuan menjadi tinggi $(20,32 \pm 2,399)$. Berdasarkan nilai signifikansinya $\mathrm{p}=0,000(\mathrm{p}<0,05)$, atau ada perbedaan bermakna antara hasil penilaian kepatuhan pasien sebelum dan setelah perlakuan/mendapatkan pelayanan berbasis Medication Therapy Management (MTM). Hasil posttest menunjukkan terjadi peningkatan dalam kategori tingkat pengetahuan. Sesuai dengan hasil yang diharapkan, apoteker dapat memegang peranan penting dalam memberikan pelayanan berbasis MTM dalam bentuk assessment, konseling dan edukasi untuk mendukung keberhasilan pengobatan. Hasil ini sesuai dengan penelitian yang dilakukan oleh Sam dkk. (2017) diperoleh hasil yaitu terdapat peningkatan pengetahuan dan kepatuhan pada pasien dengan penyakit hipertensi dengan pelayanan berbasis Medication Therapy Management (MTM) yang dilakukan oleh apoteker (Sam dkk., 2017). Penelitian lain yang dilakukan oleh Widiastuti dkk. (2019) dengan menggunakan serupa yaitu metode konseling oleh apoteker menunjukan hasil adanya peningkatan pengetahuan $(\mathrm{p}=0,000)$ sehingga terjadi peningkatan kepatuhan $(\mathrm{p}=0,000)$, terjadi penurunan tekanan darah sistolik dengan $(p=0,000)$ dan diastolik $(\mathrm{p}=0,000)$ dan kualitas hidup pasien 
meningkat dengan nilai ( $\mathrm{p}=0,001$ ) (Widyastuti dkk., 2019). Berdasarkan hasil yang diperoleh dari penelitian yang dilakukan, diharapkan program ini dapat diimplementasikan secara rutin untuk membantu pasien dengan hipertensi dimana pelayanan berbasis MTM dapat mengedepankan kolaborasi antara apoteker dengan tenaga kesehatan lainnya untuk mengoptimalisasi penggunaan obat sesuai EBM (Evidence Base Medicine) dengan melibatkan peran aktif pasien dalam mengelola kesehatannya sendiri sehingga target-target seperti peningkatan pengetahuan terkait obat dan penyakit dapat ditingkatkan sehingga dapat meningkatkan kualitas hidup serta terkontrolnya tekanan darah untuk penderita hipertensi. Distribusi skor pengetahuan responden dapat dilihat pada Tabel 3. Pada Tabel 3 dapat dilihat terjadi pengingkatan pemahaman pada sub-sub dimensi jika dibandingkan antara hasil pretest dan postest beberapa pengetahuan yang perlu ditingkatkan lagi pada sub dimensi diet tentang pemilihan jenis daging yang boleh dikonsumsi yaitu masih beberapa responden memilih daging merah dibandingkan daging putih sedangkan jawaban yang benar adalah daging putih. Untuk sub dimensi komplikasi responden mengetahui komplikasi hipertensi stroke, gagal ginjal, jantung, dan kematian dini, namun masih beberapa responden tidak mengetahui jika hipertensi bisa menyebabkan gagagl ginjal, jantung dan masih banyak responden yang tida mengetahui bahwa hipertensi dapat menyebabkan gangguan penglihatan. Dengan adanya pelayanan berbasis MTM yang terus menerus pengetahuan yang salah tersebut dapat diluruskan sehingga responden mengubah perilaku mereka.

Tingkat pendidikan merupakan karakteristik yang berkorelasi kuat terhadap pengetahuan. Apabila hasil pada Tabel 1 dianalisis dan dihubungkan dengan tingkat pengetahuan subjek penelitian, akan didapatkan hasil yang terlihat pada Tabel 3. Berdasarkan Tabel 3 dapat dilihat skor pengetahuan setelah dilakukan intervensi MTM dan diperoleh hasil yaitu rata-rata skor pengetahuan pasien dengan pendidikan yang rendah lebih rendah, semakin tinggi pendidikan maka skor pengetahuan juga semakin tinggi, tetapi berdasarkan kategori skor Hypertension Knowledge Level Scale (HK-LS) baik pasien dengan tingkat pendidikan SD, SMP, SMA atau Universitas memiliki skor kategori tinggi. Berdasarkan skor Hypertension Knowledge Level Scale (HK-LS) pasien dengan total skor 16 - 22 dapat dikategorikan pasien dengan pengetahuan tinggi. Berdasakan hasil uji statistik yang menunjukkan nilai signifikansi sebesar 0,004 ( $p<0,05)$ yang berarti bahwa terdapat pengaruh tingkat pendidikan terhadap tingkat pengetahuan pasien hipertensi yang mendapat pelayanan berbasis MTM. Tingkat pendidikan seseorang dapat mempengaruhi kemampuan serta pengetahuan dalam menerapkan perilaku hidup sehat, terutama dalam mencegah terjadinya hipertensi. Semakin tinggi tingkat pendidikan seseorang maka akan meningkatkan tingkat intelektual, sehingga lebih cepat menerima dan lebih mudah menyerap informasi yang diberikan serta memiliki pola pikir yang lebih baik terhadap penyakit dan terapi yang dijalaninya (Jankowska-Polańska dkk., 2016). Tingginya tingkat pendidikan berpengaruh terhadap skor pengetahuan pasien serta peranan apoteker dengan metode Medication Therapy Management (MTM) bermakna bagi peningkatan pengetahuan pasien mengenai penyakit hipertensi dan terapinya. Pengaruh tingkat pendidikan terhadap pengetahuan pasien hipertensi setelah dilakukan MTM dapat dilihat pada Tabel 4.

Tabel 2. Pengaruh MTM terhadap tingkat pengetahuan pasien hipertensi

\begin{tabular}{cccccc}
\hline $\begin{array}{c}\text { Kategori } \\
\text { Pengetahuan }\end{array}$ & $\begin{array}{c}\text { Tinggi } \\
\mathrm{n}(\%)\end{array}$ & $\begin{array}{c}\text { Sedang } \\
\mathrm{n}(\%)\end{array}$ & $\begin{array}{c}\text { Rendah } \\
\mathrm{n}(\%)\end{array}$ & Rata-rata skor \pm SD & Nilai p \\
\hline Pre-test & $16(36,4)$ & $25(56,8)$ & $3(6,8)$ & $14,3 \pm 3,766$ & $0,000^{*}$ \\
Pos-test & $42(95,4)$ & $2(4,5)$ & $0(0)$ & $20,32 \pm 2,399$ & \\
\hline
\end{tabular}

Keterangan: ${ }^{*} \mathrm{p}=$ taraf kepercayaan $5 \%(\mathrm{p}<0,05)$; menggunakan Uji Wilcoxon 
Tabel 3. Distribusi skor tingkat pengetahuan pasien terhadap penyakit hipertensi

\begin{tabular}{|c|c|c|c|c|c|}
\hline \multirow[b]{3}{*}{ No. } & \multirow[b]{3}{*}{ Domain } & \multicolumn{4}{|c|}{ Jawaban } \\
\hline & & \multicolumn{2}{|c|}{ Pre-test } & \multicolumn{2}{|c|}{ Pos-test } \\
\hline & & $\begin{array}{c}\text { Benar } \\
(\%)\end{array}$ & $\begin{array}{c}\text { Salah } \\
(\%)\end{array}$ & $\begin{array}{c}\text { Benar } \\
(\%)\end{array}$ & $\begin{array}{c}\text { Salah } \\
(\%)\end{array}$ \\
\hline & Definisi & & & & \\
\hline 1 & $\begin{array}{l}\text { Meningkatnya tekanan darah diastolic juga menandakan } \\
\text { meningkatnya tekanan darah }\end{array}$ & $\begin{array}{c}14 \\
(31,8)\end{array}$ & $\begin{array}{c}30 \\
(68,2)\end{array}$ & $\begin{array}{c}44 \\
(100)\end{array}$ & $\begin{array}{c}0 \\
(0)\end{array}$ \\
\hline 2 & $\begin{array}{l}\text { Tingginya tekanan darah sistolik dan diastolic menandakan } \\
\text { meningkatnya tekanan darah } \\
\text { Pengobatan }\end{array}$ & $\begin{array}{c}31 \\
(70,5)\end{array}$ & $\begin{array}{c}13 \\
(29,5)\end{array}$ & $\begin{array}{c}44 \\
(100)\end{array}$ & $\begin{array}{c}0 \\
(0)\end{array}$ \\
\hline 3 & Obat untuk hipertensi harus dikonsumsi setiap hari & $\begin{array}{c}39 \\
(88,6)\end{array}$ & $\begin{array}{c}5 \\
(11,4)\end{array}$ & $\begin{array}{c}43 \\
(97,7)\end{array}$ & $\begin{array}{c}1 \\
(2,3)\end{array}$ \\
\hline 4 & $\begin{array}{l}\text { Pasien hipertensi meminum obat hanya pada saat mereka merasa } \\
\text { sakit }\end{array}$ & $\begin{array}{l}11 \\
(25)\end{array}$ & $\begin{array}{l}33 \\
(75)\end{array}$ & $\begin{array}{c}1 \\
(2,3)\end{array}$ & $\begin{array}{c}43 \\
(97,7)\end{array}$ \\
\hline 5 & Pasien hipertensi harus meminum obat mereka seumur hidup & $\begin{array}{c}23 \\
(52,3)\end{array}$ & $\begin{array}{c}21 \\
(47,7)\end{array}$ & $\begin{array}{c}41 \\
(93,2)\end{array}$ & $\begin{array}{c}3 \\
(6,8)\end{array}$ \\
\hline 6 & $\begin{array}{l}\text { Pasien hipertensi harus meminum obat mereka secara teratur untuk } \\
\text { membuat mereka nyaman } \\
\text { Kepatuhan }\end{array}$ & $\begin{array}{c}32 \\
(72,7)\end{array}$ & $\begin{array}{c}12 \\
(27,3)\end{array}$ & $\begin{array}{c}43 \\
97,7)\end{array}$ & $\begin{array}{c}1 \\
(2,3)\end{array}$ \\
\hline 7 & $\begin{array}{l}\text { Apabila pengobatan hipertensi dapat mengontrol tekanan darah, } \\
\text { maka tidak perlu mengubah gaya hidup }\end{array}$ & $\begin{array}{c}9 \\
(20,5)\end{array}$ & $\begin{array}{c}35 \\
(79,5)\end{array}$ & $\begin{array}{c}1 \\
(2,3)\end{array}$ & $\begin{array}{c}43 \\
(97,7)\end{array}$ \\
\hline 8 & $\begin{array}{l}\text { Hipertensi adalah efek dari bertambahnya usia, jadi pengobatan } \\
\text { hipertensi tidak dibutuhkan }\end{array}$ & $\begin{array}{c}6 \\
(13,6)\end{array}$ & $\begin{array}{c}38 \\
(86,4)\end{array}$ & $\begin{array}{c}1 \\
(2,3)\end{array}$ & $\begin{array}{c}43 \\
(97,7)\end{array}$ \\
\hline 9 & $\begin{array}{l}\text { Jika pasien hipertensi mengubah gaya hidup, maka tidak perlu } \\
\text { meminum obat hipertensi }\end{array}$ & $\begin{array}{c}13 \\
(29,5)\end{array}$ & $\begin{array}{c}31 \\
(70,5)\end{array}$ & $\begin{array}{c}3 \\
(6,8)\end{array}$ & $\begin{array}{c}41 \\
(93,2)\end{array}$ \\
\hline 10 & $\begin{array}{l}\text { Pasien hipertensi dapat memakan makanan asin selama mereka } \\
\text { meminum obat secara teratur } \\
\text { Gaya Hidup }\end{array}$ & $\begin{array}{c}13 \\
(29.5)\end{array}$ & $\begin{array}{c}31 \\
(70,5)\end{array}$ & $\begin{array}{c}3 \\
(6,8)\end{array}$ & $\begin{array}{c}41 \\
(93,2)\end{array}$ \\
\hline 11 & Pasien hipertensi boleh minum minuman beralkohol & $\begin{array}{c}0 \\
(0)\end{array}$ & $\begin{array}{c}44 \\
(100)\end{array}$ & $0(0)$ & $\begin{array}{c}44 \\
(100)\end{array}$ \\
\hline 12 & Pasien hipertensi tidak boleh merokok & $\begin{array}{c}41 \\
(93,2)\end{array}$ & $\begin{array}{c}3 \\
(6,8)\end{array}$ & $\begin{array}{c}43 \\
(97,7)\end{array}$ & $\begin{array}{c}1 \\
(2,3)\end{array}$ \\
\hline 13 & Pasien hipertensi harus sering makan sayuran dan buah-buahan & $\begin{array}{c}42 \\
(95,5)\end{array}$ & $\begin{array}{c}2 \\
(4,5)\end{array}$ & $\begin{array}{c}44 \\
(100)\end{array}$ & $\begin{array}{c}0 \\
(0)\end{array}$ \\
\hline 14 & $\begin{array}{l}\text { Cara memasak makanan yang paling baik untuk pasien hipertensi } \\
\text { adalah dengan cara digoreng }\end{array}$ & $\begin{array}{c}12 \\
(27,2)\end{array}$ & $\begin{array}{l}32 \\
(72,7)\end{array}$ & $\begin{array}{c}1 \\
(2,3)\end{array}$ & $\begin{array}{c}43 \\
(97,7)\end{array}$ \\
\hline 15 & $\begin{array}{l}\text { Cara memasak makanan yang paling baik untuk pasien hipertensi } \\
\text { adalah dengan cara direbus dan dipanggang } \\
\text { Diet }\end{array}$ & $\begin{array}{c}15 \\
(34,1)\end{array}$ & $\begin{array}{c}29 \\
(65,9)\end{array}$ & $\begin{array}{c}44 \\
(100)\end{array}$ & $\begin{array}{c}0 \\
(0)\end{array}$ \\
\hline 16 & $\begin{array}{l}\text { Tipe daging yang paling baik untuk pasien hipertensi adalah daging } \\
\text { putih }\end{array}$ & $\begin{array}{c}18 \\
(40,9)\end{array}$ & $\begin{array}{c}26 \\
(59,1)\end{array}$ & $\begin{array}{c}39 \\
(88,6)\end{array}$ & $\begin{array}{c}5 \\
(11,4)\end{array}$ \\
\hline 17 & $\begin{array}{l}\text { Tipe daging yang paling baik untuk pasien hipertensi adalah daging } \\
\text { merah } \\
\text { Komplikasi }\end{array}$ & $\begin{array}{c}12 \\
(27,3)\end{array}$ & $\begin{array}{c}32 \\
(72,7)\end{array}$ & $\begin{array}{c}3 \\
(6,8)\end{array}$ & $\begin{array}{c}41 \\
(93,2)\end{array}$ \\
\hline 18 & $\begin{array}{l}\text { Hipertensi menyebabkan kematian dini apabila tidak segera } \\
\text { ditangani }\end{array}$ & $\begin{array}{c}15 \\
(34,1)\end{array}$ & $\begin{array}{c}29 \\
(65,9)\end{array}$ & $\begin{array}{c}41 \\
(93,2)\end{array}$ & $\begin{array}{c}3 \\
(6,8)\end{array}$ \\
\hline 19 & $\begin{array}{l}\text { Hipertensi dapat menyebabkan penyakit jantung, seperti serangan } \\
\text { jantung apabila tidak segera ditangani }\end{array}$ & $\begin{array}{c}18 \\
(40,9)\end{array}$ & $\begin{array}{c}26 \\
(59,1)\end{array}$ & $\begin{array}{c}39 \\
(88,6)\end{array}$ & $\begin{array}{c}5 \\
(11,4)\end{array}$ \\
\hline 20 & Hipertensi dapat menyebabkan strok apabila tidak segera ditangani & $\begin{array}{c}27 \\
(61,4)\end{array}$ & $\begin{array}{c}17 \\
(38,6)\end{array}$ & $\begin{array}{c}39 \\
(88,6)\end{array}$ & $\begin{array}{c}5 \\
(11,4)\end{array}$ \\
\hline 21 & $\begin{array}{l}\text { Hipertensi dapat menyebabkan gagal ginjal apabila tidak segera } \\
\text { ditangani }\end{array}$ & $\begin{array}{c}5 \\
(11,4)\end{array}$ & $\begin{array}{c}39 \\
(88,6)\end{array}$ & $\begin{array}{c}32 \\
(72,7)\end{array}$ & $\begin{array}{c}12 \\
(27,3)\end{array}$ \\
\hline 22 & $\begin{array}{l}\text { Hipertensi dapat menyebabkan gangguan penglihatan apabila tidak } \\
\text { segera ditangani }\end{array}$ & $\begin{array}{c}2 \\
(4,5)\end{array}$ & $\begin{array}{c}42 \\
(95,5\end{array}$ & $\begin{array}{c}16 \\
(36,4) \\
\end{array}$ & $\begin{array}{c}28 \\
(63,6)\end{array}$ \\
\hline
\end{tabular}


Tabel 4. Pengaruh tingkat pendidikan terhadap pengetahuan pasien hipertensi setelah dilakukan MTM

\begin{tabular}{ccccc}
\hline $\begin{array}{c}\text { Tingkat } \\
\text { Pendidikan }\end{array}$ & $\begin{array}{c}\text { Jumlah subjek } \\
(\mathrm{n})\end{array}$ & $\begin{array}{c}\text { Persentase } \\
(\%)\end{array}$ & $\begin{array}{c}\text { Skor Pengetahuan } \\
(\text { Rata-rata } \pm \text { SD })\end{array}$ & Nilai p \\
\hline SD & 6 & 13,6 & $17,83 \pm 2,714$ & \\
SMP & 2 & 4,5 & $20,00 \pm 1,414$ & 0,004 \\
SMA & 26 & 59,1 & $20,46 \pm 2,486$ & \\
UNIVERSITAS & 10 & 22,7 & $21,50 \pm 0,527$ & \\
\hline
\end{tabular}

Keterangan: * $\mathrm{p}=$ taraf kepercayaan 5\% ( $<<0,05)$; menggunakan Uji Kruskal Wallis

\section{Pengaruh MTM terhadap tingkat kepatuhan pasien hipertensi dan implikasinya terhadap apoteker}

Kepatuhan pasien dalam pengobatan berpengaruh terhadap keberhasilan terapi hipertensi. Hasil penelitian untuk mengetahui adanya pengaruh penerapan metode berbasis Medication Therapy Management (MTM) terhadap kepatuhan dapat dilihat pada Tabel 5. Berdasarkan data pada Tabel 5, didapatkan peningkatan jumlah pasien yang masuk kategori kepatuhan tinggi berdasarkan skor Morisky Green Level Scale (MGLS) setelah mendapatkan pelayanan berbasis MTM, semula $40,9 \%$ menjadi $86,4 \%$, jumlah pasien yang berada pada kategori kepatuhan sedang turun dari $27,3 \%$ menjadi 9,1\% serta jumlah pasien yang berada pada kategori kepatuhan rendah turun dari 31,8\% menjadi 4,5\%. Berdasarkan skor Morisky Green Level Scale (MGLS) semakin rendah skor kepatuhan maka kepatuhan semakin tinggi, nilai 0 kepatuhan tinggi, nilai 1 - 2 kepatuhan sedang dan nilai 3 - 4 kepatuhan rendah, sehingga pada penelitian ini berdasarkan hasil pre-test kategori kepatuhan pasien rata-rata memiliki kepatuhan sedang $(1,64 \pm 1,464)$ dan setelah dilakukan MTM kategori kepatuhan menjadi tinggi $(0,39 \pm 0,920)$. Berdasarkan Tabel 5 dapat dilihat bahwa terjadi penurunan skor dari hasil pre-test terhadap masingmasing pertanyaan, yang dapat diartikan bahwa terjadi peingkatan kepatuhan responder. Berdasarkan nilai signifikansi yang diperoleh $\mathrm{p}=0,000(\mathrm{p}<0,05)$ yang artinya ada perbedaan bermakna antara hasil penilaian kepatuhan pasien sebelum dan setelah perlakuan/pelayanan berbasis MTM menurut skor Morisky Green Level Scale (MGLS) pre-test dan posttest. Dapat disimpulkan dari data tersebut bahwa apoteker memiliki peran yang bermakna dalam meningkatkan kepatuhan pasien dalam pengobatan. Hal ini sesuai dengan penelitian yang dilakukan oleh Sam dkk. (2017) diperoleh hasil yaitu terdapat peningkatan kepatuhan pada pasien dengan penyakit kronis dengan menggunakan metode Medication Therapy Management (MTM) (Sam dkk., 2017). Penelitian lain yang dilakukan oleh Wittayanukorn dkk. (2013) tentang penerapan Medication Therapy Management (MTM) pada penyakit kardiovaskular dan diperoleh hasil yaitu terdapat signifikansi secara klinis dengan meningkatnya jumlah pasien yang mencapai tujuan pengobatan, tercapainya kepatuhan sehingga tekanan darah pasien hipertensi dapat terkontrol dan turunnya angka indeks Body Mass Index (BMI) (Wittayanukorn dkk., 2013). Berdasarkan penelitian yang dilakukan oleh Kristina dkk. (2019) tentang evaluasi efektivitas metode konseling oleh apoteker terhadap kepatuhan pasien terhadap obat antihipertensi dan kontrol tekanan darah, diperoleh hasil pengukuran kepatuhan pengobatan antihipertensi diukur dengan Morisky Green Levine Scale (MGLS) diperoleh hasil bahwa metode tersebut efektif untuk meningkatkan kepatuhan pengobatan dan hasil tekanan darah di antara pasien hipertensi. Efektivitas metode konseling oleh apoteker dalam meningkatkan kepatuhan pengobatan ditunjukkan oleh skor perubahan skor MGLS selama 4 minggu masa studi. Metode konseling dikaitkan dengan peningkatan skor kepatuhan (skor dari 3,5 pada pra-tes hingga 1,6 pada post-test) $(\mathrm{p}<0,05)$. Sebaliknya, untuk perawatan biasa, perubahan kepatuhan (skor dari 3,42 pada pre-test menjadi 3,50 pada post-test) tidak signifikan secara statistik. digunakan untuk pasien dengan kondisi kronis, termasuk hipertensi di negara maju.

Tabel 5. Pengaruh MTM terhadap tingkat kepatuhan pasien hipertensi

\begin{tabular}{cccccc}
\hline Kategori Kepatuhan & Tinggi n (\%) & Sedang n $(\%)$ & Rendah n (\%) & Rata-rata \pm SD & Nilai p \\
\hline Pre-test & $18(40,9)$ & $12(27,3)$ & $14(31,8)$ & $1,64 \pm 1,464$ & $0,000^{*}$ \\
Pos-test & $38(86,4)$ & $4(9,1)$ & $2(4,5)$ & $0,39 \pm 0,920$ & \\
\hline
\end{tabular}

Keterangan: $\mathrm{p}=$ taraf kepercayaan $5 \%(\mathrm{p}<0,05) ; *$ menggunakan Uji Wilcoxon

Berdasarkan hasil yang diperoleh dari penelitian yang dilakukan, diharapkan program ini dapat diimplementasikan secara rutin untuk membantu pasien dengan hipertensi, dimana pada pelayanan berbasis 
MTM yang mengedepankan kolaborasi antara apoteker dengan tenaga kesehatan lainnya dan apoteker dapat memberikan penyuluhan dan mendidik pasien mengenai penggunaan obat yang tepat dan strategi-strategi untuk menjamin kepatuhan pasien terhadap regimen pengobatan sehingga dapat meningkatkan kontrol tekanan darah untuk penderita hipertensi, serta pada pelayanan berbasis MTM semua kegiatan yang dilakukan didokumentasikan dalam buku dokumentasi sehingga diharapkan pasien melibatkan peran aktif pasien dalam mengelola kesehatannya sendiri. atau dengan penyakit kronis lainnya, kemungkinan akan meningkatkan hasil klinis dan berpotensi menghemat biaya manajemen hipertensi. Distribusi skor kepatuhan responden dapat dilihat pada Tabel 6. Pada hasil pengukuran pre-test rata-rata menyatakan bahwa mereka pernah lupa tidak meminum obat, minum obat tidak teratur, dan jika sudah merasa sehat obat mulai dihentikan. Setelah dilakukan pelayanan berbasis MTM terjadi peningkatan kepatuhan minum obat dimana ratarata menjawab mereka tidak lagi lupa meminum obat, tidak minum obat tidak teratur, dan jika sudah merasa sehat obat tidak dihentikan. Hal ini menunjukkan intervensi apoteker dengan metode pelayanan berbasis MTM yang dilakukan pada penelitian ini dapat memberikan dampak positif terhadap kepatuhan dengan nilai $\mathrm{p}=0,000$. Penelitian ini sesuai dengan penelitian sebelumnya yang menyatakan bahwa intervensi apoteker dapat menyebabkan modifikasi dalam sikap pasien terhadap terapi dan meningkatkan kepatuhan pengobatan (Saleem dkk., 2015). Menurut Swandari dkk. (2014), konseling apoteker adalah salah satu faktor penting untuk meningkatkan kepatuhan minum obat sehingga tekanan darah terkontrol. Dibutuhkan komitmen yang kuat dari pasien agar mereka patuh minum obat, sehingga peran apoteker sangat penting dalam menumbuhkan komitment tersebut.

Tabel 6. Distribusi skor tingkat kepatuhan pasien terhadap penyakit hipertensi

\begin{tabular}{|c|c|c|c|c|c|}
\hline \multirow[t]{3}{*}{ No } & \multirow[t]{3}{*}{ Pertanyaan } & \multicolumn{4}{|c|}{ Jawaban } \\
\hline & & \multicolumn{2}{|c|}{ Pre-test } & \multicolumn{2}{|c|}{ Pos-test } \\
\hline & & $\mathrm{Ya}(\%)$ & Tidak $(\%)$ & $\mathrm{Ya}(\%)$ & Tidak $(\%)$ \\
\hline 1 & Apakah anda pernah lupa minum obat? & $24(54,5)$ & $20(45,5)$ & $2(4,5)$ & $42(95.5)$ \\
\hline 2 & Apakah anda meminum obat tidak teratur? & $15(34,1)$ & $29(65,9)$ & $8(18,2)$ & $36(81,8)$ \\
\hline 3 & $\begin{array}{l}\text { Ketika anda sudah merasa sehat, apakah anda } \\
\text { menghentikan meminum obat anda? }\end{array}$ & $24(54,5)$ & $20(45,5)$ & $2(4,5)$ & $42(95,5)$ \\
\hline 4 & $\begin{array}{l}\text { Apabila anda merasa lebih sakit ketika meminum } \\
\text { obat, apakah anda menghentikan obat tersebut? }\end{array}$ & $9(20,5)$ & $35(79,5)$ & $5(11,4)$ & $39(88,6)$ \\
\hline
\end{tabular}

Kepatuhan pengobatan sangat mungkin dipengaruhi oleh beberapa hal diantaranya yaitu jenis kelamin, lama menderita dan keberadaan penyakit penyerta/komorbid (Kristina dkk., 2019). Penelitian terkait hubungan antara jenis kelamin dan tingkat kepatuhan pasien menunjukkan bahwa laki-laki memiliki tingkat kepatuhan yang lebih rendah dibanding perempuan. Hal ini dikarenakan laki-laki memiliki aktivitas yang lebih banyak sehingga tingkat kesibukannya lebih tinggi dan lebih berpeluang untuk melupakan waktu minum obatnya (Ambaw dkk., 2012). Lama pengobatan dan penyakit penyerta dapat mempengaruhi kepatuhan pasien. Semakin lama seorang pasien menjalani pengobatannya dan semakin banyak obat yang dikonsumsi maka semakin kecil pasien tersebut untuk patuh terhadap pengobatannya (Jankowska-Polańska dkk., 2016). Jika dibandingkan antara kepatuhan pengobatan pasien dengan karakteristik jenis kelamin, lama menderita dan komplikasi hasilnya dapat dilihat pada Tabel 7 . Berdasarkan data dari Tabel 7, dapat dilihat bahwa rata- rata skor kepatuhan pasien laki-laki yaitu $0,69 \pm 1,352$ dan perumpuan rata-rata skor kepatuhan yaitu $0,21 \pm$ 0,499, Berdasarkan hasil tersebut, kategori kepatuhan setelah dilakukan pelayanan berbasis MTM menurut skor Morisky Green Level Scale (MGLS) yaitu kepatuhan kategori tinggi (skor 0). Hasil uji statistik menunjukkan nilai signifikansi sebesar 0,425 ( $p>0,05)$ yang berarti bahwa tidak terdapat pengaruh jenis kelamin terhadap tingkat kepatuhan pasien hipertensi yang mendapat metode pelatihan MTM, serta peranan apoteker dengan metode Medication Therapy Management (MTM) bermakna bagi peningkatan kepatuhan minum obat. Skor kepatuhan berdasarkan lama menderita hipertensi setelah dilakukan pelayanan berbasis MTM diperoleh hasil yaitu pasien yang menderita hipertensi $<1$ tahun memiliki rata-rata skor kepatuhan 1,82 \pm 1 , 401, pasien yang menderita hipertensi 1 - 10 tahun memiliki rata-rata skor 0,46 \pm 0,905, pasien yang menderita hipertensi 11 - 19 tahun memiliki rata-rata skor $0,17 \pm 0,408$ dan pasien yang 
menderita hipertensi > 20 tahun memiliki rata-rata skor $0,00 \pm 0,000$. Berdasarkan hasil tersebut bahwa pasien yang menderita hipertensi $<1$ tahun memiliki kategori pengetahuan sedang sedangkan pasien yang menderita hipertensi 1 - 10 tahun dan lebih memiliki rata-rata kepatuhan tinggi menurut skor Morisky Green Level Scale (MGLS).

Tabel 7. Pengaruh jenis kelamin, usia, lama terapi dan penyakit penyerta terhadap kepatuhan pasien hipertensi setelah diberikan MTM

\begin{tabular}{|c|c|c|c|c|c|}
\hline Karc & teristik subjek & Jumlah subjek & Persentase & Skor kepatuhan & Nilai $p$ \\
\hline Jenis kelamin & Laki-laki & 16 & 36,3 & $0,69 \pm 1,352$ & $0,425^{\mathrm{a}}$ \\
\hline & Perumpuan & 28 & 63,6 & $0,21 \pm 0,499$ & \\
\hline Lama menderita & $<1$ tahun & 11 & 25 & $1,82 \pm 1,401$ & \\
\hline & $1-10$ tahun & 26 & 59,1 & $0,46 \pm 0,905$ & $0,673^{\mathrm{b}}$ \\
\hline & $11-19$ tahun & 6 & 13,6 & $0,17 \pm 0,408$ & \\
\hline & $>20$ tahun & 1 & 2,3 & $0,00 \pm 0,000$ & \\
\hline Komplikasi & $\mathrm{DM}$ & 7 & 15,9 & $0,14 \pm 0,378$ & \\
\hline & Hiperlipidemia & 3 & 6,9 & $0,00 \pm 0,000$ & $0,752^{\mathrm{b}}$ \\
\hline & DM + Hiperlipidemia & 4 & 9,1 & $0,25 \pm 0,500$ & \\
\hline & Tanpa Komplikasi & 30 & 68,2 & $0,50 \pm 1,075$ & \\
\hline
\end{tabular}

Keterangan: $\mathrm{p}=$ taraf kepercayaan 5\% $(\mathrm{p}<0,05){ }^{\mathrm{a}}=$ analisis menggunakan Mann Whitney; ${ }^{\mathrm{b}}$ analisis menggunakan Kruskal Walis Test

Hasil signifikansi lama pasien menderita hipertensi dengan skor kepatuhan setelah dilakukan pelayanan berbasis MTM diperoleh hasil yaitu 0,673 (p > 0,05) yang artinya tidak ada pengaruh yang signifikan antara lama pasien menderita hipertensi dengan kepatuhan pasien hipertensi setelah diberikan pelayanan berbasis MTM. Kategori kepatuhan pasien dengan penyakit penyerta dan tanpa penyakit penyerta setelah dilakukan pelayanan berbasis MTM diperoleh hasil yaitu semua pasien baik ada atau tidak penyakit penyerta memiliki kategori kepatuhan tinggi menurut skor Morisky Green Level Scale (MGLS) (skor 0) dan diperoleh nilai signifikansi 0,752 ( $\mathrm{p}>0,05)$ yang artinya tidak ada pengaruh yang signifikan antara ada atau tidaknya penyakit penyerta dengan kepatuhan pasien hipertensi setelah diberikan pelayanan berbasis MTM. Menurut Hadi \& Rostamigooran (2004), bahwa lama menderita hipertensi dan komorbid penyakit tidak mempunyai pengaruh yang signifikan terhadap kepatuhan dalam pengobatan pasien, semakin lama seorang menderita hipertensi maka semakin bertambah pengalaman pasien tersebut terhadap penyakitnya. Pengalaman dapat memperluas pengetahuan dari seseorang, semakin banyak dalam minum obat juga akan meningkat. Sehingga, peranan apoteker dengan metode Medication Therapy Management (MTM) bermakna bagi peningkatan kepatuhan pasien mengenai penyakit hipertensi dan terapinya pengalaman seseorang, maka semakin tinggi pula pengetahuan orang tersebut sehingga kepatuhan.

\section{Keterbatasan penelitian}

Pada penelitian ini terdapat beberapa keterbatasan, pertama ukuran sampel dalam penelitian ini terbatas. Kedua, penerapan pelayanan berbasis MTM dapat diterapkan meskipun penelitian sudah selesai tetapi pengukuran pengetahuan dan kepatuhan pasien hipertensi dilakukan dalam waktu yang singkat, sehingga mungkin tidak memadai untuk membuktikan efektifitas peningkatan pengetahuan dan kepatuhan pasien hipertensi sebagai hasil penerapan pelayanan berbasis Medication Therapy Management (MTM).

\section{KESIMPULAN}

Medication Therapy Management (MTM) berpengaruh secara bermakna terhadap peningkatan pengetahuan mengenai penyakit hipertensi $(p=0,000)$ dan berperan signifikan dalam meningkatkan kepatuhan pasien hipertensi $(p=0,000)$, diharapkan dengan adanya penelitian ini dapat menjadi informasi bagi apoteker terkait pelayanan berbasis Medication Therapy Management (MTM) sehingga dapat tercapainya pengetahuan dan kepatuhan yang baik terkait hipertensi dan dapat mengontrol tekanan darah pasien.

\section{UCAPAN TERIMA KASIH}

Penulis mengucapkan terima kasih kepada berbagai pihak yang telah membantu penelitian ini yaitu 
responden penelitian, Puskesmas Umbulharjo II, dan Puskesmas Mergangsan.

\section{DAFTAR PUSTAKA}

Akoko, B. M., Fon, P. N., Ngu, R. C. \& Ngu, K. B. (2017). Knowledge of Hypertension and Compliance with Therapy Among Hypertensive Patients in the Bamenda Health District of Cameroon: A Cross-sectional Study. Cardiology and Therapy; 6; 53-67.

Ambaw, A. D., Alemie, G. A., Yohannes, S. M. \& Mengesha, Z. B. (2012). Adherence to Antihypertensive Treatment and Associated Factors Among Patients on Follow Up at University of Gondar Hospital, Northwest Ethiopia. BMC Public Health; 12; 282.

Baliz, E., S., Isikli, B., Metintas, S., Kalyoncu, C. (2012). Hypertension Knowledge-Level Scale (HK-LS): A Study on Development, Validity and Reliability. International Journal of Environmental Research and Public Health; 9; 1018-1029.

Beyhaghi, H., Reeve, B. B., Rodgers, J. E. \& Stearns, S. C. (2016). Psychometric Properties of the FourItem Morisky Green Levine Medication Adherence Scale among Atherosclerosis Risk in Communities Study (ARIC) Participants. Value Health; 19; 996-1001.

Dipiro, T. J., Robert, L. T., Gary, C. Y., Gary, R. M., Barbara, G. W., L. \& Michael, P. (2017). Pharmacotherapy a Pathophysiologic Approarch 10th Edition Chapter 13: Hypertension. New York: McGraw Hill.

Hadi, N. \& Rostamigooran, N. (2004). Determinant Factors of Medication Compliance in Hypertensive Patients of Shiraz, Iran. Archives of Iranian Medicine; 7; 292-296.

Jankowska-Polańska, B., Uchmanowicz, I., Dudek, K. \& Mazur, G. (2016). Relationship between Patients \& RSQUO; Knowledge and Medication Adherence Among Patients with Hypertension. Patient Preference and Adherence; 10; 24372447.

Kemenkes RI. (2013). Riset Kesehatan Dasar Republik Indonesia. Jakarta: Kementerian Kesehatan Republik Indonesia.

Kristina, S. A., Dewi, P. P., Widiastuti, W. (2019). Effectiveness of Counseling for Hypertensive Patients on Adherence and Blood Pressure Outcome in Primary Care Provider in Indonesia.
International Research Journal of Pharmacy; 10; 40-44.

Lee, G. K. Y., Wang, H. H. X., Liu, K. Q. L., Cheung, Y., Morisky, D. E., Wong, M. C. S. (2013). Determinants of Medication Adherence to Antihypertensive Medications among a Chinese Population Using Morisky Medication Adherence Scale. PLoS ONE; 8; e62775.

Ribeiro, C. D., Resqueti, V. R., Lima, I., Dias, F. A. L., Glynn, L. \& Fregonezi, G. A. F. (2015). Educational Interventions for Improving Control of Blood Pressure in Patients with Hypertension: A Systematic Review Protocol. BMJ Open; 5; e006583-e006583.

Saleem, F., Azmi, M. \& Shafie, A. (2015). A CrossSectional Assessment of Health-Related Quality of Life (HRQoL) Among Hypertensive Patients in Pakistan. Health Expectations; 17; 288-925.

Sam, G. K., Thomas, J., Alexander, R. \& Varughese, S. A. (2017). Assessment \& Evaluation on the Knowledge, Attitude \& Practice Towards Medication Therapy Management Among Community of Davangere City. Asian Journal of Pharmaceutical and Clinical Research; 10; 380.

Swandari, M. T. K., Sari, I. P. \& Kusharwanti, A. W. (2014). Evaluasi Pengaruh Konseling Farmasis terhadap Kepatuhan dan Hasil Terapi Pasien Hipertensi di Poliklinik Penyakit Dalam RSUD Cilacap Periode Desember 2013 - Januari 2014. Jurnal Manajemen dan Pelayanan Farmasi; 4; 219-229.

WHO. (2003). Adherence to Long-Term Therapies Evidence for Action. WHO: Geneva.

Widyastuti, S., Yasin, N. M \& Kristina, S. A. (2019). Pengaruh Home Pharmacy Care Terhadap Pengetahuan, Kepatuhan, Outcome Klinik dan Kualitas Hidup Pasien Hipertensi. Majalah Farmaseutik; 15; 105.

Wittayanukorn, S., Westrick, S. C., Hansen, R. A., Billor, N., Braxton-Lloyd, K., Fox, B. I., Garza, K. B. (2013). Evaluation of Medication Therapy Management Services for Patients with Cardiovascular Disease in a Self-Insured Employer Health Plan. Journal of Managed Care \& Specialty Pharmacy; 19; 385-395. 